\title{
'Simplexus' in ComPlexUs: Meeting the Challenge of Complexity Sciences
}

\author{
Henri Atlan
}

fter 2 years, ComPlexUs seems to meet a widespread demand. In different fields researchers feel the need for new tools in order to confront, analyze and understand the complexity of the real world. Postgenomic biology, or functional genomics or 'systems biology', as it is also named, provide many opportunities to test this new paradigm. However, similar problems are encountered in other disciplines, such as sociology, psychology, and economics, while similar tools are borrowed from physics, mathematics and computer sciences. Previous and current issues contain several articles with new insights in the fields not only of function- al genomics, proteomics and cell biology, but also health management, transportation systems, neuroendocrinology and psychology. Special issues are in preparation on the complexity of the microbial world, including contributions to the 'European Conference on Complex Systems', Paris, 2005.

As usual, in such multidisciplinary attempts, new difficulties are encountered in bridging communication gaps between different technical jargons. To overcome this difficulty, ComPlexUs has introduced an editorial novelty. Under the name of 'Simplexus', a companion text composed by a scientific writer is systematically printed in association with each technical article. It provides a qualitative 'translation' into a language accessible to most readers across different disciplines. The challenge of complexity sciences is to make complex systems simpler to understand, without falsely reducing their complexity.

\section{Fax +41613061234 E-Mail karger@karger.ch www.karger.com}

KARGER
C) 2005 S. Karger AG, Base 1424-8492/05/0021-0001 $\$ 22.00 / 0$

Accessible online at: www.karger.com/cpu
Prof. Henri Atlan

Ecole des Hautes Etudes en Sciences Sociales 54, Bd Raspail, F-75006 Paris (France)

Fax + 33143355309

E-Mail henri.atlan@ehess.fr
Prof. Henri Atlan

Dept. of Medical Biophysics and Nuclear Medicine Human Biology Research Center, Hadassah Hospital Kiryat Hadassah, PO Box 12000, Jerusalem 91120 (Israel) Fax+ 972642 1203, E-Mail atlan@hadassah.org.il 